\title{
REVIEWS AND REPORTS
}

\author{
POROČILA
}

\section{YEARS OF CARSOLOGICA SINICA}

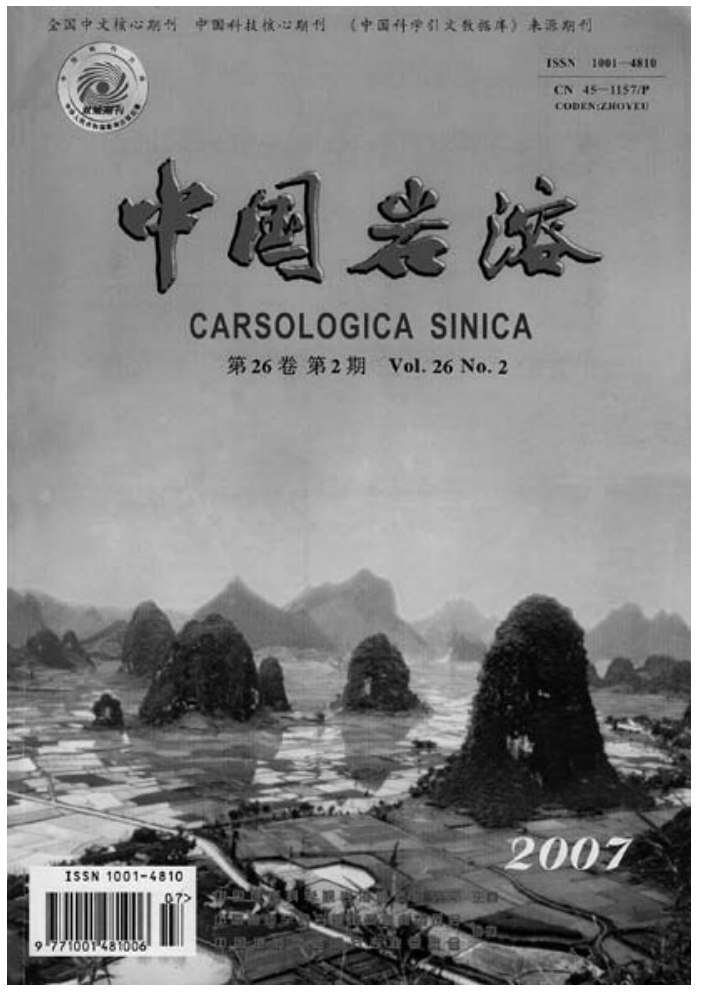

In 1982 Chinese karstologists from the Institute of Karst Geology at Guilin started the quarterly journal CARSOLOGICA SINICA (ZHONGGUO YANRONG). The journal is under the aegis of Chinese Academy of Geological Sciences, patronized by the Commission of Karst Geology and by the Committee of Speleology in the frame of Geological Society of China. And not only sponsored but also edited and published by the well known Institute of Karst Geology at Guilin in the heart of world famous tower karst along the river Li. Chinese karstologists not only started but they succeeded to edit the journal through the quarter of a century without interruption. In this year number 1 and 2 of the volume 26 have been published already.

The major topics of Carsologica Sinica include basic theories, hydrogeology and engineering, environmental and ecological geology, geography, forestry, agriculture, tourism, and the environment protection. Of course, all the topics are related to karst. According to the topics is

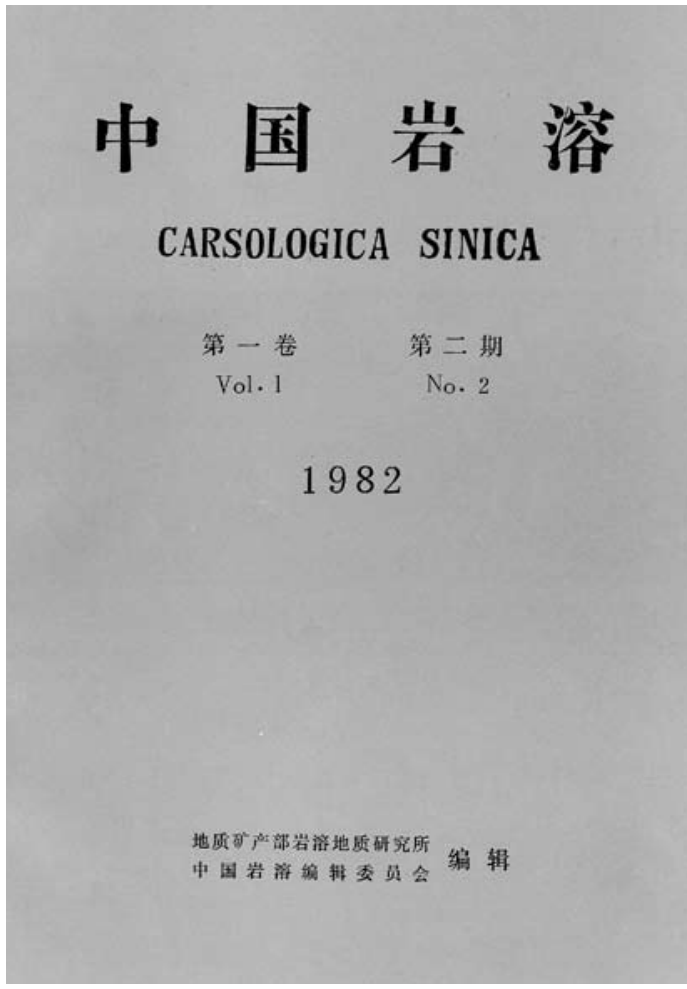

the circle of the readers and users of the journal. Carsologica Sinica is high ranked among the periodical publications of China and it is included in different foreign (Georef, Pascal, International Union of Speleology, Current Titles of BCRA and others) and in leading Chinese databases. Of the last mentioned Carsologica Sinica has high input factor $(0.54-0.84)$ and it is ranked between $181-399$ of 1608 Chinese publications. By an interesting and quite unknown indicator, the rate of error lower than $2 \mathrm{o} / \mathrm{oo}$, the journal is ranked very high too. The high appreciation of the journal must not surprise regarding the immense and so various Chinese karst and the fact that Carsologica Sinica is the only public academic publication in the field of karstology in China.

In 25 volumes of Carsologica Sinica there are more than 1200 papers. The emphasis is on the fundamental karst research, on development of karst resources and on applied research of karst resources exploitation and protection. If we compare the source of information for the 
articles there is quite a big difference between Carsologica Sinica and western journals of the same type: here the source are mainly (80 \%) National Natural Science Foundation Projects and National Scientific and Technological Key Projects. It is difficult to estimate journal's great contribution to the science of karst. For sure among the authors there are eminent and the most known Chinese karstologists, that means known worldwide. In the first volume (1982) already appeared the names of Yang Mingde and Zhu Dehau, the colleagues which the members of Karst Research Institute from Postojna met often in China or in Slovenia. At that time the article on limestone caves in Guilin area was published by Prof. Zhu Xuewen. Looking the contents of the last number (volume 26) there is the article on Wulong karst system by the same author. Among younger authors known to Western karstologists I have a pleasure to mention Chen Weihai. For Western sphere maybe it is easier to imagine importance of the authors by citing Marjorie M. Sweeting and Peter Bull (Great Britain), Claude Drogue (France) and Paul Williams (New Zealand) as few examples.

In 25 years also the image and technical possibilities developed. First numbers measured $18 \times 26 \mathrm{~cm}$, while the recent ones are of bigger dimensions $(21 \times 30 \mathrm{~cm})$. At the beginning the cover was simple in one colour while volume 26 (2007) has a nice full page colour photo of "fenglin" karst. Likewise can be said for the inner pages where there are colour illustrations now. It is worthy from the point of non-Chinese speaking readers that from the first numbers already most of the papers have an English abstract or summary. In the volume 26 there are also key words, texts to the illustrations, and some additional explanations in English. It is self-understanding that the papers of foreign authors are in English. But recently there are also papers of Chinese authors, published in English in Carsologica Sinica, for example "Geophysical Pros- pecting of Karst Water in Yunnan Province" by Wang Yu, Yuan Dao-xian and Yang Shi-yu. But there are exceptions regarding foreign authors too: in 2006 a Supplement to volume 25 was published with 11 papers of foreign authors talking about "tiankengs" - in Chinese.

The last but not least the editors have to be mentioned too. 18 years the post and heavy duty of Editorin-Chief was held by Yuan Dao-xian succeeded by Liu Zai-hua, also very important figure in Chinese karstology. They were helped for a long time by Assistant ChiefEditor Wei Fucai. To help to and to support the editorial policy foreign karstologists are included into the editorial board, A. N. Palmer, J. M. James, T. Waltham, W. Dreybrodt and the author of this report.

By my opinion the "Western" karstologists are using the information and data mainly upon karst in China accumulated in 25 volumes of Carsologica Sinica far too little. The language barrier is very important but it must not be decisive. English abstracts, summaries, key words, together with illustrations can be important source of Chinese examples of karst as well as a window to the thoughts and notion of karst by Chinese researchers. In spite of bibliographical bases Carsologica Sinica is included it is much less used and appreciated as it should be. It is seen by the citations as well as the use by researchers in libraries. To be honest, the journal is not so wide spread in Europe and so it is not easy to get wanted number or article. I guess that there is no complete issue of 25 volumes in the whole Slovenia, Karst research Institute library included.

What kind of good wish to express for this 25th anniversary? To keep on the work, to keep on the quality of the contents and of the layout of the journal and disseminate it as largely as possible.

Andrej Kranjc 